九州大学学術情報リポジトリ

Kyushu University Institutional Repository

\title{
Impact of Agricultural Market Reform on Pulses Market Integration in Myanmar
}

\section{Aung, Kyaw Moe}

Department of agricultural and Resource Economics, Graduate School of Bioresource and Bioenvionmental Sciences, Kyushu University

Yutaka, Tomoyuki

Department of agricultural and Resource Economics, Graduate School of Bioresource and Bioenvionmental Sciences, Kyushu University

Fukuda, Susumu

Department of agricultural and Resource Economics, Graduate School of Bioresource and Bioenvionmental Sciences, Kyushu University

Kai, Satoshi

Department of agricultural and Resource Economics, Graduate School of Bioresource and Bioenvionmental Sciences, Kyushu University

https://doi.org/10.5109/10111

出版情報：九州大学大学院農学研究院紀要. 53 (1)，pp.337-347，2008-02-28. Faculty of Agriculture, Kyushu University

バージョン :

権利関係 : 


\title{
Impact of Agricultural Market Reform on Pulses Market Integration in Myanmar
}

\author{
Aung Kyaw MOE ${ }^{1}$, Tomoyuki YUTAKA, Susumu FUKUDA \\ and Satoshi KAI* \\ Laboratory of Food Marketing, Division of Industrial Organization of Agribusiness, \\ Department of Agricultural and Resource Economics, Faculty of Agriculture, \\ Kyushu University, Fukuoka 812-8581, Japan \\ (Received November 9, 2007 and accepted November 30, 2007)
}

\begin{abstract}
Since 1988, agricultural market reform had been implemented with domestic and export liberalization in Myanmar. However, pulses market is only one market implemented by fully privatization of marketing activities both in domestic and abroad. This paper tests the impact of agricultural market reform on regional wholesale markets of pulses by using Johansen's multivariate co-integration method and Granger causality test. All price series were integrated order (1). One co-integrating equation was found in long-run for all markets, but there was disequilibrium condition in short run market integration. Mandalay prices Granger caused all prices of markets of black gram and green gram, and Yangon prices Granger caused all markets except Myingyan in pigeon pea. Yangon and Mandalay markets are the leading markets for price formation. Agricultural market reform with domestic and export liberalization is a necessary condition for efficient marketing system, but is not a sufficient condition for this system. It can be concluded that efficient marketing system should be improved with agricultural market reform meanwhile strengthening market information system, market facilities and institutions.
\end{abstract}

\section{INTRODUCTION}

Recently, many developing countries have been pursuing agricultural market reforms in structural adjustment program. The objectives of market reform are to reduce market-distorting practices, to increase market efficiency, and to integrate markets across regions and countries. If agricultural markets are not integrated, producers and consumers will not attain the benefits from market liberalization, the correct price signal will not be transmitted through the marketing channels, resulting which the farmers will not be able to specialize according to long-term competitive advantage and the gains from trade will not be realized in full (Ravallion, 1986).

Spatial market integration refers to a situation in which prices of a commodity in spatially separated markets move together, thereby offer smooth transmission of price signal and information. Therefore, spatial market performance may be evaluated in terms of the relationship between the prices of spatially separated markets, and spatial price behavior in regional markets, which is termed as an assessment of overall market performance.

Granger causality is a tool for analyzing price linkages of markets. A lead/lag relationship of price series can be tested by causality test. And then, the directions of price formation and market competition can be examined by this method. The peculiar characteristic of this

\footnotetext{
1 Laboratory of Food Marketing, Division of Industrial Organization of Agribusiness, Department of Agricultural and Resource Economics, Graduate School of Bioresource and Bioenvironmental Sciences, Kyushu University

* Corresponding author (E-mail: satokai@agr.kyushu-u.ac.jp)
}

test is able to understand the movement of prices among markets.

The combination of above two models will be able to access for some extent of policy change on marketing performance. The economy of the Union of Myanmar was under a centrally planned system from 1962 to 1988, under the Burmese Way of Socialism. However, it adopted a market-economic system and direct government intervention had been gradually reduced together with economic reform measures since 1988. The economic reforms have had a significant impact on agriculture sector, since reform included the liberalization of agricultural pricing and marketing policies from compulsory procurement system of major crops. The objective of this paper is to assess the impact of agricultural market reform on regional wholesale markets of pulses by using Johansen's multivariate co-integration test and Granger causality test.

\section{WHOLESALE MARKETS OF PULSES IN MYANMAR}

The type of wholesale markets can be classified based on function and size of markets. There are two main types of markets in Myanmar, major crop exchange centers like Yangon and Mandalay and regional or district level crop exchange centers like Pyay, Monywa, Myingyan and Pakokku. Major crop exchange centers are the largest wholesale markets in the country, where are operated by many large-scale wholesalers and exporters dealing in different kinds of agricultural products. And then, these centers influence the formation of price on regional wholesale markets. Regional crop exchange centers are the medium-scale wholesale markets and play the key role of collection and distribution 
Table 1. Name of Major Pulses Dealing in Wholesale Markets

\begin{tabular}{ll}
\hline Markets & \multicolumn{1}{c}{ Name of Major Pulses } \\
\hline Yangon & Black gram, Green gram, Pigeon pea, Cow pea, Lablab bean, Soybean \\
Mandalay & Black gram, Green gram, Pigeon pea, Cow pea, Lablab bean, Soybean \\
Pyay & Black gram, Green gram, Cow pea, Lablab bean, \\
Monywa & Green gram, Pigeon pea, Chick pea Garden pea \\
Myaingyan & Green gram, Pigeon pea, Chick pea Garden pea \\
Pakkoku & Green gram, Pigeon pea, Chick pea Garden pea \\
\hline
\end{tabular}

channels of agricultural products within inter-regional markets and also major transition points of trade flow from townships to major crop exchange centers.

Most of pulses are marketed to major exchange centers from regional markets and production area. Varieties of pulses handling in markets depend on the kind of these, cultivated by production area nearby each market. Major pulses and wholesale markets are illustrated in Table 1.

\section{Yangon Market (Bayint Naung Market)}

Bayint Naung Market is a big and modern wholesale market constructed in 1990. The location of the market is strategic area with easy access by truck from all parts of the country. There are two big truck parking lots and two mooring places for access by boat. It deals in dry commodities such as rice, pulses, onion, potato, dried chili and garlic, fishery products and agricultural inputs. The market is managed by Yangon City Development committee. The revenue of market taxed by YCDC was over 2,400 million kyat, about one fourth of total revenue of YCDC, for budget year 1998/99.

Bayint Naung Crop Exchange Center is located inside the compound of the market and is the focal point of marketing of dry goods especially pulses. It was established in 1991 by Yangon Division of the Chamber of Commence and Industry. Now, it is organized and managed by association of Yangon Division Traders and Industrialists that has over 1,000 members. This center operates daily except Sunday and national holidays. Marketing activities of pulses, maize, oilseeds crop, onion, dried chili, garlic and potato are conducted from 9 a.m to 12 a.m. The samples of crops are displayed on the tables in the center describing the available volume. Buyers examine the samples and bargain about the price. Pulses buyers negotiate the price based on the information of export price. On reaching an agreement, the representatives record the negotiated price in their register books and the seller has to pay a commission 0.25 kyat per bag to the representative.

The information of the recorded negotiated price is transmitted by the traders and wholesalers to their clients in regional and township markets with phones. There are no publications of price information in the center.

\section{Mandalay Market}

In Mandalay, there is a famous and long history crop exchange center (negotiation wholesale center) established by brokers, merchants and millers of the Maha Kahetin Daw Association as a religious society in 1935.
This association has about 1,500 members, mainly wholesalers, traders and oil millers. The center operates daily except Sabbath days (lunar calendar) and national holidays. The center deals in trading of pulses, maize, oilseeds crop, sorghum and miller from 8 to 10 a.m. and edible oil after 11 a.m to 1 p.m.

The pattern of trading of crops in Mandalay is the same as that in Yangon market. But the staffs of the center in Mandaly record the negotiated price on register book and write on the blackboard. Mandalay market operates trading of pulses not only with Yangon market, but also with border trade of China. Therefore, Mandalay market is a leading market for the formation of price of pulses.

\section{Pyay Market}

Pyay market is located within Bago division and has a newly established crop exchange center. It is situated in almost middle point between Yangon and Mandalay markets and is an important trading and transit point. Pyay has a good and smooth motor road connection with Yangon.

\section{Monywa Market}

Monywa market is located within Sagaing division and is the main trading center. It is connected well by motor road, river and railway. Monywa wholesalers trade directly with Yangon wholesalers and exporters by receiving 1\% commission fee. Monywa crop exchange center is well-established and well-staffed. There is an information sub-committee responsible for recording and duplicating price lists which cover 44 types of crops.

\section{Myingyan Market}

Myaingyan market is located within Mandalay division. Among pulses, Pigeon pea is a main crop of trading of Myaingyan market. This market is well connected with Pakkoku market in Magway division. It has a trader association and crop exchange center established in 1994 with 268 members.

\section{Pakkoku Market}

Pakkoku market has the highest marketing activity in Magway division. Although it is relatively small, there is a high concentration of collectors and wholesalers in different parts of the town.

\section{TRENDS AND BEHAVIOR OF PRICES IN REGIONAL WHOLESALE MARKETS}

Price trends of domestic markets for black gram, 


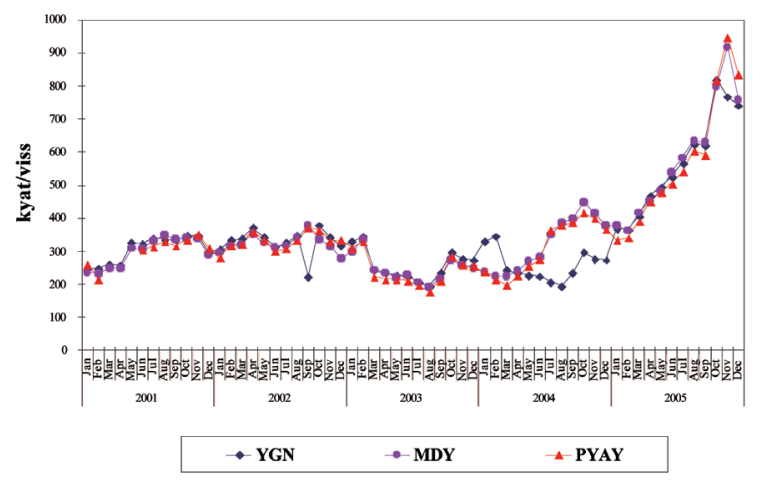

Fig. 1a. Price Trends of Black Gram in Major Wholesale Markets.

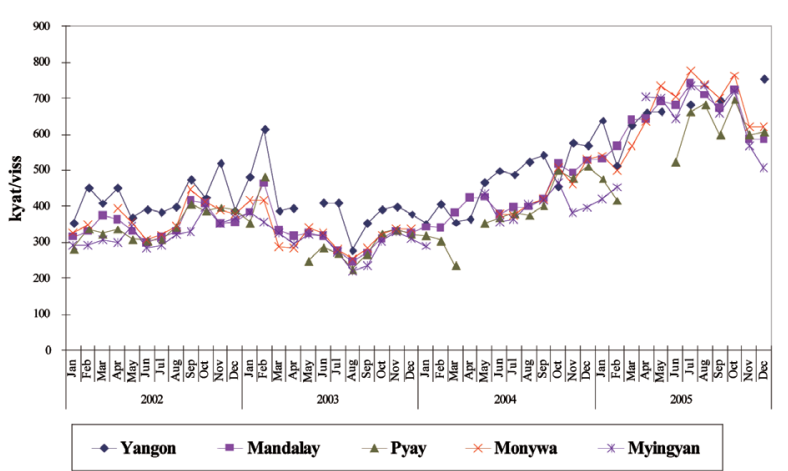

Fig. 1b. Price Trends of Green Gram in Major Wholesale Markets.

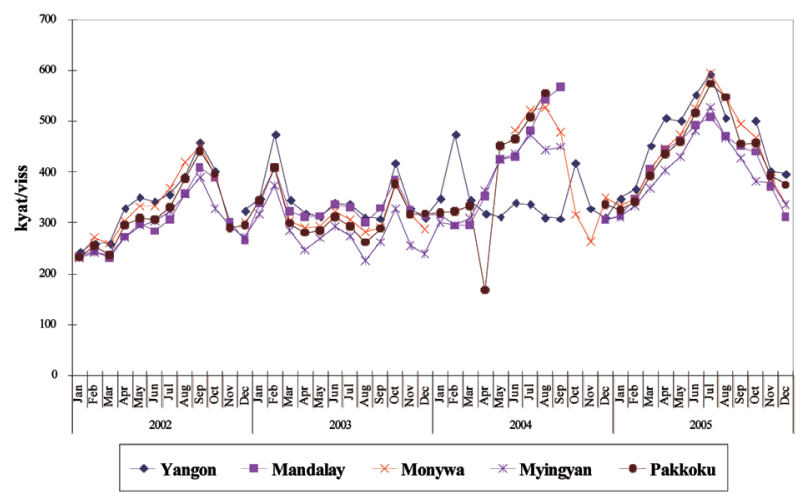

Fig. 1c. Price Trends of Pigeon pea in Major Wholesale Markets.

green gram and pigeon pea are shown in Fig. 1(a), 1(b) and 1 (c) respectively.

All trends of prices of black gram, green gram and pigeon pea fluctuated month by month and year by year depending on export price, market exchange rate of US\$, and supply condition of pulses. Among pulses, black gram prices were more stable and more integrated within markets than that of green gram and pigeon pea. The pattern of price trend for green gram and pigeon pea did not synchronize among domestic markets.

\section{Descriptive Analysis of Price in Regional Wholesale Markets}

Descriptive analysis of monthly prices for Black gram, Green gram, and Pigeon pea in domestic markets are shown in Tables 2(a), 2(b) and 2(c) respectively.

Variability of prices in wholesale markets is meas-
Table 2a. Descriptive Analysis of Monthly Prices for Black Gram

(kyat/viss)

\begin{tabular}{cccccc}
\hline Markets & Mean & Std. Dev. & CV & Minimum & Maximum \\
\hline Yangon & 346 & 141 & 0.41 & 194 & 818 \\
Mandalay & 359 & 149 & 0.42 & 192 & 918 \\
Pyay & 354 & 154 & 0.43 & 179 & 947 \\
\hline
\end{tabular}

Table 2b. Descriptive Analysis of Monthly Prices for Green Gram (kyat/viss)

\begin{tabular}{cccccc}
\hline Markets & Mean & Std. Dev. & CV & Minimum & Maximum \\
\hline Yangon & 477 & 112 & 0.23 & 280 & 754 \\
Mandalay & 406 & 119 & 0.29 & 246 & 742 \\
Pyay & 390 & 104 & 0.27 & 227 & 663 \\
Monywa & 413 & 119 & 0.29 & 255 & 776 \\
Mingyan & 371 & 107 & 0.29 & 221 & 734 \\
\hline
\end{tabular}

Table 2c. Descriptive Analysis of Monthly Prices for Pigeon Pea (kyat/viss)

\begin{tabular}{cccccc}
\hline Markets & Mean & Std. Dev. & CV & Minimum & Maximum \\
\hline Yangon & 377 & 85 & 0.23 & 242 & 593 \\
Mandalay & 359 & 81 & 0.22 & 232 & 543 \\
Monywa & 375 & 92 & 0.25 & 234 & 595 \\
Mingyan & 334 & 81 & 0.24 & 225 & 528 \\
Pakkoku & 368 & 93 & 0.25 & 232 & 574 \\
\hline
\end{tabular}

ured by coefficient of variation. Coefficient of variation of black gram was calculated based on the data from JAN, 2001 to DEC, 2005 and it ranged from the value of 0.41 to 0.43 . These of green gram and pigeon pea were calculated based on the data from JAN, 2002 to DEC, 2005 and the range was from 0.23 to 0.29 for Green gram and 0.22 to 0.25 for Pigeon pea. Black gram markets had the highest value of coefficient of variation because of huge and prompt increase of prices in 2005. Price of black gram in India increased significantly in 2005 and consequently, price of domestic markets of black gram increased significantly in 2005. Therefore, the formation of domestic price of pulses depends on international price especially India for being the destination of about 80\% export pulses from Myanmar.

\section{Seasonal Variation of Price in Regional Wholesale Markets}

Seasonality is another source of variability in prices. Seasonal price behavior is a regularly repeating price pattern that is completed once over 12 months. Such a regular pattern might arise from seasonality in demand, seasonality in supply and marketing, or a combination of the two. Seasonal index of pulses price was computed by using 12 month -moving average method. The results of seasonal price movements for Black gram, Green gram, and Pigeon pea are illustrated in Fig. 2(a), 2(b) and 2 (c) respectively.

Seasonality of prices is usually a reflection of seasonality of production, with prices showing a tendency to decline during the harvest season and to increase during the off season. Cropping calendar of pulses is shown in Fig. 3.

Black gram can be grown almost exclusively in lower 


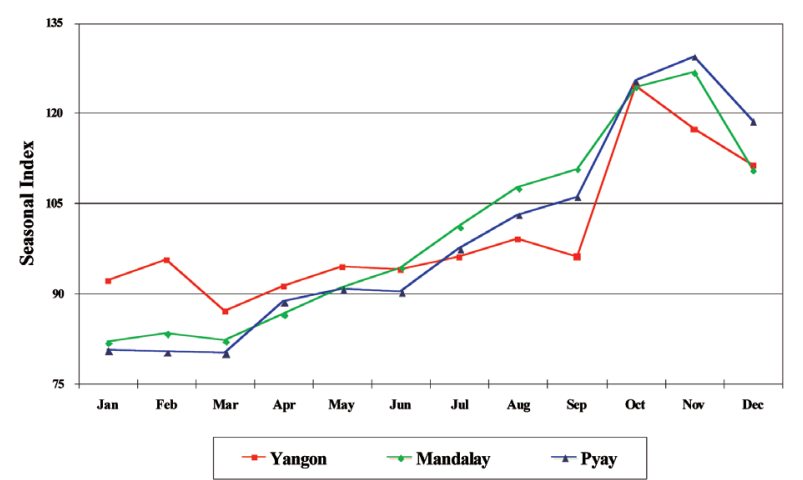

Fig. 2a. Seasonal Index of Black gram Wholesale Prices (2001-2005).

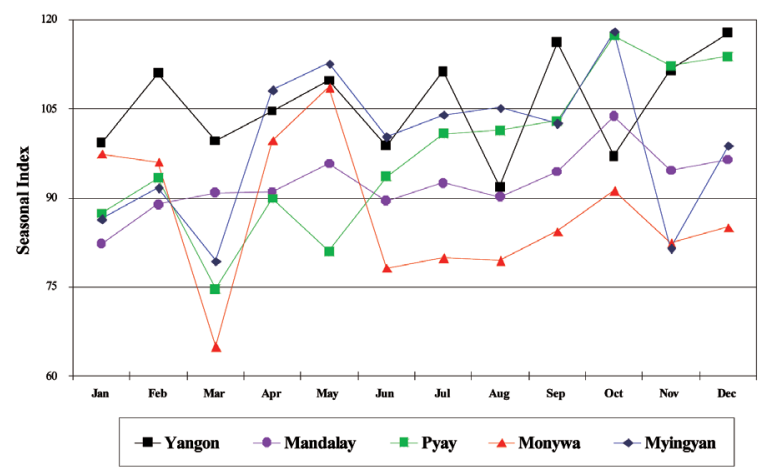

Fig. 2b. Seasonal Index of Green gram Wholesale Prices (2002-2005).

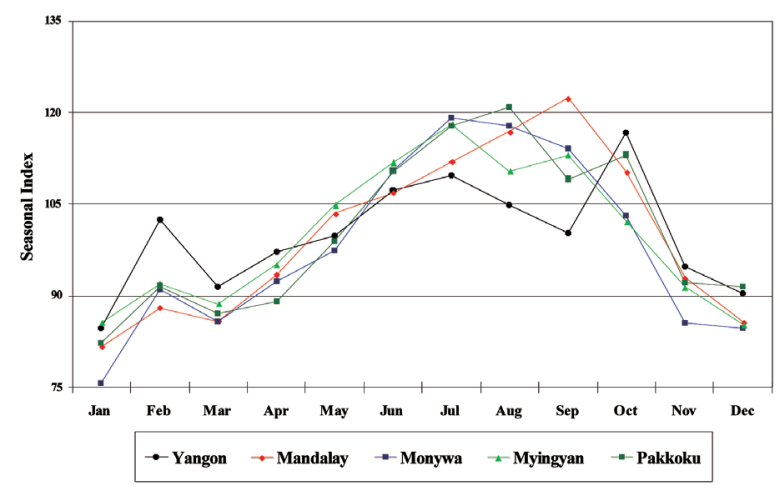

Fig. 2c. Seasonal Index of Pigeon pea Wholesale Prices (2002-2005).

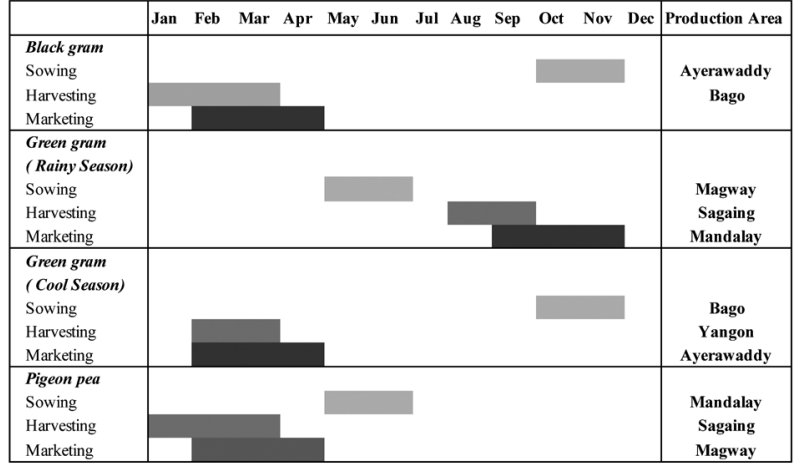

Fig. 3. The Calendar of Sowing, Harvesting and Marketing of Major Pulses in Myanmar.

Myanmar, Yangon, Ayeyarwaddy and Bago divisions, on paddy field after monsoon crop, in cool season. Sowing is in November-December and harvesting is FebruaryMarch. Seasonal index of black gram fell down to the lowest level from February to March during harvesting period (Fig. 2a). Then, price increased gradually from April to November during the off season. The peak of price was October and November just before harvesting season.

Green gram is grown both in central Myanmar where it is cultivated mainly in rainy season and lower Myanmar where it is grown only in the cool season on paddy field after monsoon crop. Sowing season of central Myanmar is on May-June and harvesting season is on AugustSeptember. Sowing time of lower Myanmar is on November-December and harvesting is February-March. The two falling points of price could be observed in March and August of the two harvesting seasons. The peak seasons of price were May and October (Fig. 2b).

Pigeon pea can be grown almost exclusively in the central dry zone. Pigeon pea is cultivated only in the monsoon season, planted from May to June and harvested from January to February. The lowest point of price was on December and January because of harvesting time. The highest time of price was on August to October just before harvesting (Fig. 2c).

Summary statistics for wholesale price seasonality of regional wholesale markets is shown in Table (3).

Table 3. Summary Statistics for Wholesale Price Seasonality of Regional Wholesale Markets

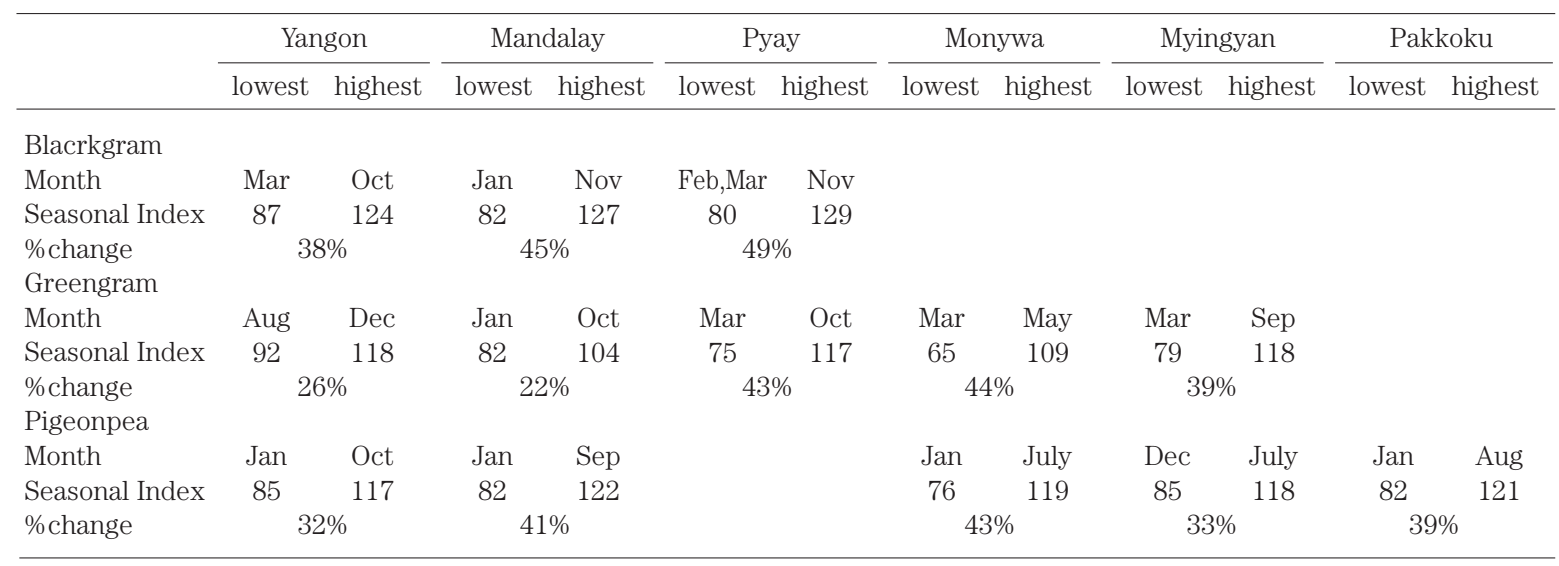


The gap between the highest and lowest point of seasonal index is a very important factor for price stabilization and arbitrage power for storage of pulses. The percentage changes of seasonal variation of black gram, green gram and pigeon pea ranged from 38\% to 49\%, $22 \%$ to $44 \%$, and $32 \%$ to $43 \%$ respectively. The difference of seasonality of all pulses was quiet large. Therefore, storage of pulses after harvest and resale at the off season is very profitable. The duration of storage will be 6-7 months for black gram and pigeon pea to achieve profit. But, green gram takes the time about 2 months for first season and 4 months for second season of storage to get arbitrage benefit. Storage facilities and credits are essential to reduce high variation of seasonal movement of price and stabilize the price.

\section{METHODOLOGY}

Among several different methods of market integration, co-integration test and error correction mechanism are very useful in integration analysis because co-integration can be tested for the presence of a non-spurious long-run equilibrium relationship between the variables under study in a multivariate setting with and without a time trend and error correction mechanism enable researchers to estimate the speed of adjustment back to the long-run condition among the variables.

There are two co-integration methods: EngleGranger Method and Johansen's Method. Engle-Granger method is two-step procedure to test co-integration and generally used in the bivariate situation. This method cannot identify the number of co-integration vectors. If the number of variables is more than two, Engel and Granger approach also cannot estimate the parameters efficiently. In contrast to Engel-Granger method, Johansen's test is one-step procedure to test co-integration instead of two steps in former method. And then, Johansen's approach can be tested not only the estimation of co-integration vectors, but also the estimation of the short run dynamics of the system. Therefore, Johansen's method, first proposed by Johansen (1998) and Johansen and Juselius (1990), is used in this study. Johansen's test is capable of determining the number of co-integrating vectors for any given number of non-stationary series of the same order.

\section{Unit root test}

Before testing for co-integration, a unit root test is required to ensure that the variables under study are non-stationary I (1). The co-integration test is only applicable if the variables are of the same order (1). The augmented Dickey-Fuller (ADF) test (Dickey and Fuller, 1979 and 1981) is used to test for the order of integration. To test unit root, the $\mathrm{ADF}$ test is based on the following regression equation (1):

$$
\Delta X_{t}=\alpha+\delta X_{t-1}+\sum_{k=1}^{p} \gamma_{k} \Delta X_{t-k}+\varepsilon_{t}
$$

$X_{t}=$ the relevent time-series

Where, $\Delta=$ the first-difference operator $\varepsilon_{t}=$ an error term

The lag-length for the ADF equation is determined based on Schwartz criterion. The null hypothesis of non-stationary is tested using the t-statistic with critical values calculated by MacKinnon (1991). The null hypothesis is that $\delta$ is zero and alternative hypothesis is that $\delta$ is less than zero. The null hypothesis of the variables are non-stationary time-series is rejected if $\delta$ is less than zero and statistically significant.

\section{Testing for the lag length}

Before applying the Johansen's approach, it should be determined firstly the lag length or order of the vector auto-regression (VAR). It is a key element in the specification of the VAR, which forms the basis of inference for the co-integration rank. The most commonly used criteria are the Akaike Information Criterion (AIC) and Schwarz Bayesian Criterion (SBC). These are given as:

$$
\begin{aligned}
& A I C=\ln |\Omega(\hat{r}, p)|+(2 / T) m \\
& S B C=\ln |\Omega(\hat{r}, p)|+(\ln T / T) m \\
& \hat{\Omega}(r, p)=\hat{\varepsilon} \hat{\varepsilon} / T, \\
& m=\text { the number of freely estimated parametersin } \\
& \quad \text { a VAR model of lag=p and cointegrating rank=r, } \\
& \text { ere, } \\
& \hat{\varepsilon_{t}}=\text { a residual vector in the restricted rank VAR. } \\
& \text { ln= natural log, and } \\
& T=\text { the number of observations }
\end{aligned}
$$
Where,

When using AIC or SBC based on the estimated standard errors in respective equation, the model with the lowest value for the AIC or SBC is chosen. The dominant practice is to choose lag length (p) using one and or both of the information criteria plus the requirements that there should be no evidence of serial correlation. Then, Johansen procedure is used to determine the cointegrating rank.

\section{Johansen's Co-integration Test}

Johansen (1998) and Johansen and Juselius (1990) formulate the process for determining the co-integrating rank as follows. Consider an unrestricted VAR model up to $\mathrm{k}$ lags in which the process $X_{t}$ for given values of $X_{k+1}, \ldots \ldots, X_{0}$, can be defined as;

$$
X_{t}=\alpha+\Pi_{1} X_{t-1}+\ldots \ldots+\prod_{k} X_{t-k}+\varepsilon_{t},(t=1,2, \ldots \ldots, T)
$$

Where $X_{t}$ is a vector of I (1) variable, $\alpha$ is a vector of constant, and $\varepsilon_{t}$ is error term. Since $X_{t}$ is I (1), the equation (4) can be expressed in first-differenced error correction form as follows:

$$
\begin{aligned}
& \text { Where, } \\
& \qquad \begin{array}{l}
\Gamma_{i}=-\left(\mathrm{I}-\Pi-\ldots-\Pi_{i}\right), i=1, \ldots \ldots, k-1 \\
\quad \text { and } \Pi=-\left(\mathrm{I}-\Pi_{1}-\ldots-\Pi_{k}\right)
\end{array}
\end{aligned}
$$$$
\Delta X_{t}=\alpha+\Gamma_{1} \Delta X_{t-1}+\ldots \ldots+\Gamma_{k-1} \Delta X_{t-k+1}+\Pi_{t-k}+\varepsilon_{t}
$$ 
The coefficient matrix $\Pi$ provides information about long-run relationships between the variables in the data vector. There are three possible implications. If the rank of $\Pi=p$, it implies that the matrix $\Pi$ has full rank and the vector process $X_{t}$ is stationary. If the rank of $\Pi=0$ the matrix is a null matrix and equation would be a traditional differenced vector time-series model. If $0<\gamma<p$, it indicates that there exist $\mathrm{r}$ co-integrating vectors; in such a case $\Pi=\alpha \beta$ ', where $\alpha$ and $\beta$ are $p \times r$ matrices. The co-integrating vectors $\beta$ have the property that $\beta^{\prime} X_{t}$ is stationary even if $X_{t}$ itself is non-stationary.

The Johansen procedure gives two likelihood ratio tests for the number of co-integrating vectors: (1) the maximum eigenvalue test $\left(\lambda_{\max }\right)$, which tests the null hypothesis that there are at least $\mathrm{r}$ co-integrating vectors, as against the alternative that there are $\mathrm{r}+1$; (2) the trace-test $\left(\lambda_{\text {trace }}\right)$, where the alternative hypothesis that the number of co-integrating vectors is equal to or less than $r+1$. The likelihood ratio test statistics are as follows:

$$
\begin{aligned}
& \lambda_{\max }=-T \ln \left(1-\hat{\lambda}_{r+1}\right) \\
& \lambda_{\text {trace }}=-T \sum_{i=r+1}^{n} \ln \left(1-\hat{\lambda}_{i}\right)
\end{aligned}
$$

Where, $\hat{\lambda}_{r+1}, \ldots \ldots . \hat{\lambda}_{n}$ are n-r smallest estimated eigenvalues in equation (7), T is the sample size, and $\hat{\lambda}_{i}$ are the ordered (estimated) eigenvalues $\lambda_{1}>\lambda_{2}>\ldots .>\lambda_{n}$.

\section{Granger Causality Test}

Granger Causality test is a commonly used econo- metric method for causality test. According to Granger (1969), Y is said to "Granger-cause" $\mathrm{X}$ if and only if $\mathrm{X}$ is better predicted by using the past values of $\mathrm{Y}$ than by not doing so with the past values of $\mathrm{X}$ being used in either case. If a scalar $\mathrm{Y}$ can help to forecast another scalar X, then it can be said that Y Granger-cause X. If Y causes $X$ and $X$ does not cause $Y$, it is said that unidirectional causality exists from $Y$ to $X$. If $Y$ does not cause $X$ and $X$ does not cause $Y$, then $X$ and $Y$ are statistically independent. If $Y$ causes $X$ and $X$ causes $Y$, it is said that feedback exists between X and Y. Essentially, Granger's definition of causality is framed in terms of predictability.

To implement the Granger test, a particular autoregressive lag length $\mathrm{k}$ or $\mathrm{p}$ is assumed and the following equations are estimated by maximum likelihood method.

$$
\begin{aligned}
& X_{t}=\lambda_{1}+\sum_{i=1}^{k} \alpha_{1 i} X_{t-i}+\sum_{j=1}^{k} \beta_{1 j} Y_{t-j}+\mu_{1 t} \\
& Y_{t}=\lambda_{2}+\sum_{i=1}^{p} \alpha_{2 i} X_{t-i}+\sum_{j=1}^{p} \beta_{2 j} Y_{t-j}+\mu_{2 t}
\end{aligned}
$$

F test is carried out for the null hypothesis of no Granger causality.

$$
H_{0}=b_{i 1}=b_{i 2}=\ldots=b_{i k}=0, i=1,2 .
$$

Where, $\mathrm{F}$ statistics is the Wald statistic for the null hypothesis. If the $\mathrm{F}$ statistic is greater than a certain

\begin{tabular}{|c|c|c|c|c|c|c|c|c|}
\hline \multirow{2}{*}{ Markets } & \multirow{2}{*}{ Obs } & \multicolumn{3}{|c|}{ Unit root-test on price levels } & \multirow{2}{*}{ Obs } & \multicolumn{3}{|c|}{ Unit root-test on first difference } \\
\hline & & $\mathrm{ADF}^{1}$ & $\delta$ & $\mathrm{t}$-value ${ }^{2}$ & & $\mathrm{ADF}^{1}$ & $\delta$ & t-value ${ }^{2}$ \\
\hline Yangon & 58 & $\mathrm{ADF}(1)$ & -0.267 & -1.829 & 58 & $\operatorname{ADF}(0)$ & -1.215 & -9.271 \\
\hline Mandalay & 59 & $\mathrm{ADF}(0)$ & 0.014 & 0.331 & 59 & $\operatorname{ADF}(0)$ & -0.933 & -6.099 \\
\hline Pyay & 55 & $\mathrm{ADF}(0)$ & 0.048 & 0.977 & 53 & $\operatorname{ADF}(0)$ & -0.843 & -5.731 \\
\hline
\end{tabular}
critical value for $\mathrm{F}$ distribution, then the null hypothesis is rejected that $\mathrm{Y}$ does not Granger-cause $\mathrm{X}$ (equation (8)), which means Y Granger-cause X in long run.

Table 4a. Unit Root Test on Black Gram Price Series in Domestic Markets

Note: (1) In the column ADF the number of lags that was allowed for in the unit root teet is indicated in brackets, based on the Schwartz criteion. ADF analysis was carried out in Eviews. 5.

\begin{tabular}{|c|c|c|c|c|c|c|c|c|}
\hline \multirow{2}{*}{ Markets } & \multirow{2}{*}{ Obs } & \multicolumn{3}{|c|}{ Unit root-test on price levels } & \multirow{2}{*}{ Obs } & \multicolumn{3}{|c|}{ Unit root-test on first difference } \\
\hline & & $\mathrm{ADF}^{1}$ & $\delta$ & $\mathrm{t}$-value ${ }^{2}$ & & $\mathrm{ADF}^{1}$ & $\delta$ & $\mathrm{t}$-value $\mathrm{v}^{2}$ \\
\hline Yangon & 34 & $\mathrm{ADF}(2)$ & -0.417 & -2.015 & 36 & $\operatorname{ADF}(0)$ & -1.449 & -9.69 \\
\hline Mandalay & 47 & $\operatorname{ADF}(0)$ & -0.05 & -1.029 & 46 & $\mathrm{ADF}(0)$ & -1.114 & -7.442 \\
\hline Pyay & 34 & $\operatorname{ADF}(1)$ & -0.072 & -1.037 & 34 & $\operatorname{ADF}(0)$ & -1.257 & -7.162 \\
\hline Monywa & 39 & $\operatorname{ADF}(0)$ & -0.047 & -0.818 & 36 & $\operatorname{ADF}(0)$ & -1.105 & -6.544 \\
\hline Mingyan & 41 & $\operatorname{ADF}(0)$ & -0.097 & -1.94 & 38 & $\mathrm{ADF}(0)$ & -1.157 & -7.058 \\
\hline
\end{tabular}

(2) Critical values are given in MacKinnon: $t=-2.92,5 \%$ level of significance.

Source: Monthly Prices of Black gram from Jan-2001 to Dec-2005.

Market Information Service, Department of Agricultural Planning, Ministry of Agriculture and Irrigation.

Table 4b. Unit Root Test on Green Gram Price Series in Domestic Markets

Note: (1) In the column ADF the number of lags that was allowed for in the unit root teet is indicated in brackets, based on the Schwartz criteion. ADF analysis was carried out in Eviews. 5.

(2) Critical values are given in MacKinnon: $t=-2.92,5 \%$ level of significance.

Source: Monthly Prices of Green gram from Jan-2002 to Dec-2005.

Market Information Service, Department of Agricultural Planning, Ministry of Agriculture and Irrigation. 
Table 4c. Unit Root Test on Pigeon Pea Price Series in Domestic Markets

\begin{tabular}{|c|c|c|c|c|c|c|c|c|}
\hline \multirow{2}{*}{ Markets } & \multirow{2}{*}{ Obs } & \multicolumn{3}{|c|}{ Unit root-test on price level } & \multirow{2}{*}{ Obs } & \multicolumn{3}{|c|}{ Unit root-test on first difference } \\
\hline & & $\mathrm{ADF}^{1}$ & $\delta$ & $t$-value ${ }^{2}$ & & $\mathrm{ADF}^{1}$ & $\delta$ & t-value ${ }^{2}$ \\
\hline Yangon & 43 & $\mathrm{ADF}(0)$ & -0.327 & -2.995 & 37 & $\operatorname{ADF}(1)$ & -1.681 & -6.776 \\
\hline Mandalay & 42 & $\mathrm{ADF}(1)$ & -0.175 & -2.004 & 40 & $\operatorname{ADF}(1)$ & -1.001 & -5.001 \\
\hline Monywa & 34 & $\mathrm{ADF}(1)$ & -0.248 & -2.784 & 34 & $\operatorname{ADF}(1)$ & -0.74 & -4.52 \\
\hline Mingyan & 44 & $\operatorname{ADF}(0)$ & -0.135 & -1.749 & 42 & $\mathrm{ADF}(0)$ & -0.854 & -5.361 \\
\hline Pakkoku & 43 & $\mathrm{ADF}(0)$ & -0.252 & -2.282 & 41 & $\operatorname{ADF}(0)$ & -1.183 & -7.484 \\
\hline
\end{tabular}

Note: (1) In the column ADF the number of lags that was allowed for in the unit root teet is indicated in brackets, based on the Schwartz criteion. ADF analysis was carried out in Eviews. 5.

(2) Critical values are given in MacKinnon: $t=-2.92,5 \%$ level of significance.

Source: Monthly Prices of Pigeon pea from Jan-2002 to Dec-2005.

Market Information Service, Department of Agricultural Planning, Ministry of Agriculture and Irrigation.

\section{RESULTS AND DISCUSSIONS}

\section{Step 1: Testing for stationary}

Using the ADF test, the results present in Tables 4a, $4 \mathrm{~b}$ and $4 \mathrm{c}$. The price series for all markets of black gram, green gram and pigeon pea were I (1). For all price series, the unit root test (with an intercept) showed that the coefficients $x_{t-1}$ of were not significantly different from zero, and none of the price series was stationary. Furthermore, the unit root test on first differences (with an intercept) confirmed the opposite, which led us to conclude that all series were integrated order (1).

\section{Step 2: Testing for the lag length}

In VAR analysis, Akaike Information Criterion (AIC) and Schwarz Bayesian Criterion (SBC) were used to select a suitable lag length. The results of the test could be quite sensitive to the lag length so it was important to be careful. Begin with the longest lag length deemed reasonable and test whether the lag length can be shortened (Walter Enders, 1995). The suitable lag lengths with the smallest value for both AIC and SC were 1-lag in black gram and pigeon pea, and 2-lag in green gram.

Table 5a. Testing for the number of Co-integrating Relations (Black Gram)

\begin{tabular}{|c|c|c|c|c|}
\hline Ho: & $\mathrm{H}_{\mathrm{A}}:$ & & 95\% Critical Value & Hypothesized \\
\hline$\lambda$ trace tests & & $\lambda$ trace value & & No. of $\mathrm{CE}(\mathrm{s})$ \\
\hline$r=0$ & $r>0$ & 25.28923 & 24.27596 & None * \\
\hline$r \leq 1$ & $r>1$ & 10.14903 & 12.3209 & At most 1 \\
\hline$r \leq 2$ & $r>2$ & 0.133053 & 4.129906 & At most 2 \\
\hline$\lambda \max$ tests & & $\lambda \max$ value & & \\
\hline$r=0$ & $\mathrm{r}=1$ & 15.1402 & 17.7973 & None \\
\hline $\mathrm{r}=1$ & $\mathrm{r}=2$ & 10.01597 & 11.2248 & At most 1 \\
\hline $\mathrm{r}=2$ & $\mathrm{r}=3$ & 0.133053 & 4.129906 & At most 2 \\
\hline
\end{tabular}

Note : If the value of $\lambda$-trace and/or $\lambda$-max exceeds the critical value, we reject the null hypothesis and accept the alternative of more co-integration vectors.

Table 5b. Testing for the number of Co-integrating Relations (Green Gram)

\begin{tabular}{|c|c|c|c|c|}
\hline Ho: & $\mathrm{H}_{\mathrm{A}}:$ & & $95 \%$ Critical Value & Hypothesized \\
\hline$\lambda$ trace tests & & $\lambda$ trace value & & No. of CE(s) \\
\hline$r=0$ & $r>0$ & 77.09262 & 60.06141 & None * \\
\hline$r \leq 1$ & $r>1$ & 36.44623 & 40.17493 & At most 1 \\
\hline $\mathrm{r} \leq 2$ & $r>2$ & 17.19921 & 24.27596 & At most 2 \\
\hline $\mathrm{r} \leq 3$ & $r>3$ & 6.90366 & 12.3209 & At most 3 \\
\hline$r \leq 4$ & $r>4$ & 0.596487 & 4.129906 & At most 4 \\
\hline$\lambda \max$ tests & & $\lambda \max$ value & & \\
\hline $\mathrm{r}=0$ & $\mathrm{r}=1$ & 40.64639 & 30.43961 & None \\
\hline $\mathrm{r}=1$ & $r=2$ & 19.24703 & 24.15921 & At most 1 \\
\hline$r=2$ & $r=3$ & 10.29555 & 17.7973 & At most 2 \\
\hline $\mathrm{r}=3$ & $\mathrm{r}=4$ & 6.307173 & 11.2248 & At most 3 \\
\hline$r=4$ & $\mathrm{r}=5$ & 0.596487 & 4.129906 & At most 4 \\
\hline
\end{tabular}

Note : If the value of $\lambda$-trace and/or $\lambda$-max exceeds the critical value, we reject the null hypothesis and accept the alternative of more co-integration vectors. 
Table 5c. Testing for the number of Co-integrating Relations (Pigeon pea)

\begin{tabular}{|c|c|c|c|c|}
\hline Ho: & $\mathrm{H}_{\mathrm{A}}:$ & & 95\% Critical Value & Hypothesized \\
\hline$\lambda$ trace tests & & $\lambda$ trace value & & No. of CE(s) \\
\hline $\mathrm{r}=0$ & $r>0$ & 75.095 & 60.061 & None * \\
\hline $\mathrm{r} \leq 1$ & $r>1$ & 37.130 & 40.175 & At most 1 \\
\hline $\mathrm{r} \leq 2$ & $r>2$ & 13.629 & 24.276 & At most 2 \\
\hline $\mathrm{r} \leq 3$ & $r>3$ & 5.327 & 12.321 & At most 3 \\
\hline $\mathrm{r} \leq 4$ & $r>4$ & 0.102 & 4.130 & At most 4 \\
\hline$\lambda \max$ tests & & $\lambda \max$ value & & \\
\hline$r=0$ & $\mathrm{r}=1$ & 37.965 & 30.440 & None \\
\hline $\mathrm{r}=1$ & $\mathrm{r}=2$ & 23.501 & 24.159 & At most 1 \\
\hline $\mathrm{r}=2$ & $\mathrm{r}=3$ & 8.302 & 17.797 & At most 2 \\
\hline $\mathrm{r}=3$ & $\mathrm{r}=4$ & 5.225 & 11.225 & At most 3 \\
\hline $\mathrm{r}=4$ & $\mathrm{r}=5$ & 0.102 & 4.130 & At most 4 \\
\hline
\end{tabular}

Note : If the value of $\lambda$-trace and/or $\lambda$-max exceeds the critical value, we reject the null hypothesis and accept the alternative of more co-integration vectors.

\section{Step 3: Determining the number of co-integrating equations}

The main task in this step is to determine the rank of $\Pi$ and to estimate the co-integrating equations. Using Johansen co-integration test available in Eviews-5, the rank of $\Pi$ could be determined. The results of $\lambda_{\text {trace }}$ and $\lambda_{\max }$ indicated that the rank of $\Pi$ was 1 in all markets of pulses (Tables 5a, 5b and 5c).

\section{Step 4: Testing for long-run integration}

For the long-run price co-integration in pulses markets, the following equations 10, 11 and 12 were normalized according to the rank, defined in step 3. One co-integration equation was obtained for all markets of black gram, green gram and pigeon pea.

Long Run Integration of Black gram Price

Yangon=-7.38 Mandalay + 8.403 Pyay

$$
(-3.389) * * * \quad(3.786) * * *
$$

Long Run Integration of Green gram Price

$$
\begin{aligned}
& \text { Yangon=0.052 Mandalay-3.237 Pyay+2.542 Monywa } \\
& (0.111)^{\mathrm{ns}} \quad(-6.615)^{* * *} \quad(4.582)^{* * *} \\
& \text { +1.877 Myingyan } \\
& (7.930) * * *
\end{aligned}
$$

Long Run Integration of Pigeon pea Price

$$
\begin{aligned}
& \text { Yangon }=-0.371 \text { Mandalay }+1.230 \text { Monywa } \\
& (-1.33)^{*} \\
& (1.629)^{*} \\
& \text { - 2.50 Myingyan + 2.447 Pakkoku } \\
& (-2.667) * * * \quad(2.492) * * *
\end{aligned}
$$

For black gram markets, Yangon was significantly co-integrated with Mandalay and Pyay in long-run and the coefficients were elastic in these markets. In green gram markets, Yangon was significantly co-integrated with Pyay, Monywa and Myingyan except Mandalay. The coefficients of Pyay, Monywa and Myingyan were elastic and significant while the coefficient of Mandalay was not only in-significant, but also in-elastic. In pigeon pea markets, Yangon was significantly co-integrated in longrun with all markets, Mandalay, Monywa, Myingyan and Pakkoku. Although the coefficient of Mandalay was inelastic, the coefficients of other markets were elastic.
The extent of market integration of Yangon with Mandalay is quiet weak comparing with that of other markets because Mandalay market is as large as Yangon and can export to China by border trade.

\section{Step 5: Testing for short-run integration with a vector error correction model (VECM)}

Testing for short-run integration could be incorporated in VECM using the same price series, only when long-run integration was observed. A principal feature of co-integrated variables was that their time paths were influenced by the extent of any deviation from the longrun equilibrium (Walter Anders, 1995). Error correction term represents percent of correction to any deviation in long-run equilibrium price in a single period and also represents how fast the deviations in the long-run equilibrium are corrected.

In black gram, all markets had unstable disequilibrium effects because positive equilibrium elasticities allowed the possibility of price bubbles, in that during disequilibrium, the market prices tended to move away from the long-run equilibrium for periods of time (Table 6a). In green gram markets, all elasticities were either positive or insignificant except Pyay market. About 54\% of total deviation from long-run equilibrium will be corrected within a month in Pyay market (Table 6b). In pigeon pea, the elasticies of Yangon, Moywa and Myingyan markets were positive and significant (Table $6 c)$.

\section{Granger Causality Test}

The results of granger causality tests of all markets are shown in Tables 7a, 7b and 7c. The null hypothesis that $\mathrm{X}$ does not cause $\mathrm{Y}$ was rejected based on suitably large values of $\mathrm{F}$ statistic. The lag-length was also determined based on significant statistic of $\mathrm{F}$. The lag-length of green gram and pigeon pea were larger than that of black gram market.

The direction of Granger-causality of pulses markets are illustrated in Fig. 4(a), 4(b) and 4(c). In black gram, Yangon prices Granger caused Pyay prices and Mandalay prices caused Yangon prices with unidirectional move- 
Table 6a. Estimation of the Dynamic in the Short-run by using VECM (Black Gram)

\begin{tabular}{cccc}
\hline Error Correction: & $\mathrm{D}(\mathrm{YGN})$ & $\mathrm{D}(\mathrm{MDY})$ & $\mathrm{D}(\mathrm{PYAY})$ \\
\hline CointEq1 & $\begin{array}{c}0.068757 \\
(-0.03097)\end{array}$ & $\begin{array}{c}0.066521 \\
(-0.02706)\end{array}$ & $\begin{array}{c}0.096802 \\
(-0.02786) \\
\end{array}$ \\
{$[2.22009]^{* *}$} & {$[2.45832]^{* * *}$} & {$[3.47449]^{* * *}$} \\
\hline
\end{tabular}

Note: The value in (...) are standard errors and those in $[\ldots]$ are $t$-values. $* * *=$ significant at $1 \%, * *=$ significant at $5 \%, *=$ significant at $10 \%$, ns=not significant.

Table 6b. Estimation of the Dynamic in the Short-run by using VECM (Green Gram)

\begin{tabular}{clllll}
\hline Error Correction: & $\mathrm{D}(\mathrm{YGN})$ & $\mathrm{D}(\mathrm{MDY})$ & $\mathrm{D}(\mathrm{PYAY})$ & $\mathrm{D}(\mathrm{MYW})$ & $\mathrm{D}(\mathrm{MGN})$ \\
\hline \multirow{2}{*}{ CointEq1 } & $\begin{array}{c}-0.309739 \\
(-0.39474)\end{array}$ & $\begin{array}{c}-0.007049 \\
(-0.22774)\end{array}$ & $\begin{array}{c}-0.539826 \\
(-0.25513)\end{array}$ & $\begin{array}{c}0.243994 \\
(-0.24989)\end{array}$ & $\begin{array}{c}0.484167 \\
(-0.1918)\end{array}$ \\
& {$[-0.78467]^{\text {]s }}$} & {$[-0.03095]^{\text {ns }}$} & {$[-2.11585]^{* *}$} & {$[0.97639]^{\text {ns }}$} & {$[2.52430]^{* *}$} \\
\hline
\end{tabular}

Note: The value in (...) are standard errors and those in [...] are t-values. ${ }^{* * *}=$ significant at $1 \%,{ }^{* *}=$ significant at $5 \%, *=$ significant at $10 \%$, ns=not significant.

Table 6c. Estimation of the Dynamic in the Short-run by using VECM (Pigeon pea)

\begin{tabular}{cccccc}
\hline Error Correction: & D(YGN) & D(MDY) & D(MYW) & D(MGN) & D(PKK) \\
\hline CointEq1 & $\begin{array}{c}0.468 \\
(-0.14894)\end{array}$ & $\begin{array}{c}0.083 \\
(-0.11765)\end{array}$ & $\begin{array}{c}0.327 \\
(-0.14324)\end{array}$ & $\begin{array}{c}0.327 \\
(-0.1465)\end{array}$ & $\begin{array}{c}0.137 \\
(-0.1406)\end{array}$ \\
& {$[3.14319]^{* * *}$} & {$[0.70548]^{\text {ns }}$} & {$[2.28058]^{* *}$} & {$[2.23102]^{* *}$} & {$[0.97550]^{\text {ns }}$} \\
\hline
\end{tabular}

Note: The value in (...) are standard errors and those in [...] are t-values. ${ }^{* * *}=$ significant at $1 \%, * *=$ significant at $5 \%, *=$ significant at $10 \%$, ns=not significant.

Table 7a. Granger Causality Test on Black Gram Price Series

\begin{tabular}{ccc}
\hline Directions & Lags & F-Test \\
\hline YGN $\Rightarrow$ MDY & 1 & $2.299^{\text {ns }}$ \\
YGN $\Rightarrow$ PYAY & 1 & $3.897^{*}$ \\
MDY $\Rightarrow$ YGN & 1 & $4.891^{* *}$ \\
MDY $\Rightarrow$ PYAY & 1 & $10.852^{* * *}$ \\
PYAY $\Rightarrow$ YGN & 1 & $2.396^{\text {ns }}$ \\
PYAY $\Rightarrow$ MDY & 1 & $3.884^{*}$ \\
\hline
\end{tabular}

Note: $* * *=$ significant at $1 \%, * *=$ significant at $5 \%, *=$ significant at $10 \%$, ns $=$ not significant.

Table 7b. Granger Causality Test on Green Gram Price Series

\begin{tabular}{ccc}
\hline Directions & Lags & F-Test \\
\hline YGN $\Rightarrow$ MDY & 1 & $0.082^{\text {ns }}$ \\
YGN $\Rightarrow$ PYAY & 6 & $32.302^{* * *}$ \\
YGN $\Rightarrow$ MYW & 1 & $0.759^{\text {ns }}$ \\
YGN $\Rightarrow$ MGN & 1 & $5.911^{* *}$ \\
MDY $\Rightarrow$ YGN & 1 & $28.717^{* * *}$ \\
MDY $\Rightarrow$ PYAY & 1 & $7.279 * *$ \\
MDY $\Rightarrow$ MYW & 2 & $2.845^{*}$ \\
MDY $\Rightarrow$ MGN & 1 & $2.871^{*}$ \\
PYAY $\Rightarrow$ YGN & 6 & $6.839 *$ \\
PYAY $\Rightarrow$ MDY & 1 & $0.400^{\text {ns }}$ \\
PYAY $\Rightarrow$ MYW & 5 & $25.363^{* * *}$ \\
PYAY $\Rightarrow$ MGN & 6 & $50.658^{* * *}$ \\
MYW $\Rightarrow$ YGN & 1 & $26.487^{* * *}$ \\
MYW $\Rightarrow$ MDY & 2 & $0.535^{\text {ns }}$ \\
MYW $\Rightarrow$ PYAY & 5 & $0.412^{\text {ns }}$ \\
MYW $\Rightarrow$ MGN & 7 & $26.780^{* *}$ \\
MGN $\Rightarrow$ YGN & 1 & $15.240^{* * *}$ \\
MGN $\Rightarrow$ MDY & 1 & $0.302^{\text {ns }}$ \\
MGN $\Rightarrow$ PYAY & 6 & $3.062^{\text {ns }}$ \\
MGN $\Rightarrow$ MYW & 7 & $0.940^{\text {ns }}$ \\
& &
\end{tabular}

Note: $* * *=$ significant at $1 \%, * *=$ significant at $5 \%, *=$ significant at $10 \%$, ns=not significant.
Table 7c. Granger Causality Test on Pigeonpea Price Series

\begin{tabular}{ccc}
\hline Directions & Lags & F-Test \\
\hline YGN $\Rightarrow$ MDY & 1 & $5.155^{* *}$ \\
YGN $\Rightarrow$ PKK & 5 & $6.052^{* * *}$ \\
YGN $\Rightarrow$ MYW & 4 & $3.824^{* *}$ \\
YGN $\Rightarrow$ MGN & 2 & $1.294^{\text {ns }}$ \\
MDY $\Rightarrow$ YGN & 1 & $0.047^{\text {ns }}$ \\
MDY $\Rightarrow$ PKK & 1 & $15.06^{* * *}$ \\
MDY $\Rightarrow$ MYW & 6 & $36.412^{* * *}$ \\
MDY $\Rightarrow$ MGN & 1 & $0.783^{\text {ns }}$ \\
PKK $\Rightarrow$ YGN & 5 & $0.556^{\text {ns }}$ \\
PKK $\Rightarrow$ MDY & 1 & $0.657^{\text {ns }}$ \\
PKK $\Rightarrow$ MYW & 1 & $2.795^{\text {ns }}$ \\
PKK $\Rightarrow$ MGN & 1 & $3.009^{*}$ \\
MYW $\Rightarrow$ YGN & 4 & $1.120^{\text {ns }}$ \\
MYW $\Rightarrow$ MDY & 6 & $6.014^{*}$ \\
MYW $\Rightarrow$ PKK & 1 & $4.143^{*}$ \\
MYW $\Rightarrow$ MGN & 6 & $1.535^{\text {ns }}$ \\
MGN $\Rightarrow$ YGN & 2 & $2.763^{*}$ \\
MGN $\Rightarrow$ MDY & 1 & $2.374^{\text {ns }}$ \\
MGN $\Rightarrow$ PKK & 1 & $32.386^{* * *}$ \\
MGN $\Rightarrow$ MYW & 6 & $7.945^{*}$ \\
\hline
\end{tabular}

Note: $* * *=$ ignificant at $1 \%, * *=$ significant at $5 \%, *=$ significant at $10 \%, \mathrm{n}=$ not significant.

ment and Pyay prices with bidirectional movement. In green gram, Mandalay prices caused all market prices. Yangon prices caused Pyay and Myingyan price feedback. Pyay prices caused Moywa and Myingyan prices with unidirectional movement and caused Yangon feedback. Moywa prices caused Yangon prices. Myingyan prices were caused by all market prices. In pigeon pea, Yangon prices caused all market prices except Myingyan. But, Myingyan caused Yangon prices. There are two 


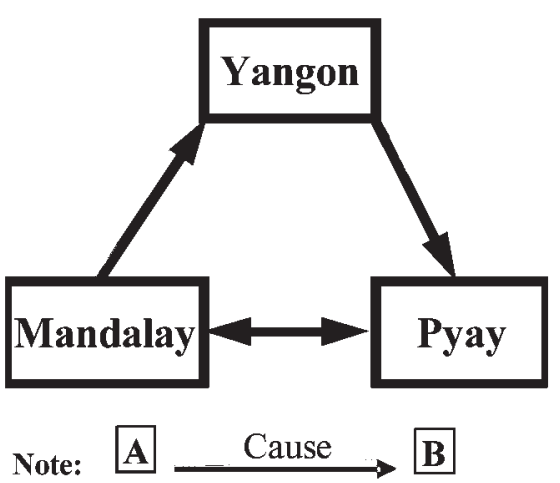

Fig. 4a. The direction of Causality of Black Gram Price.

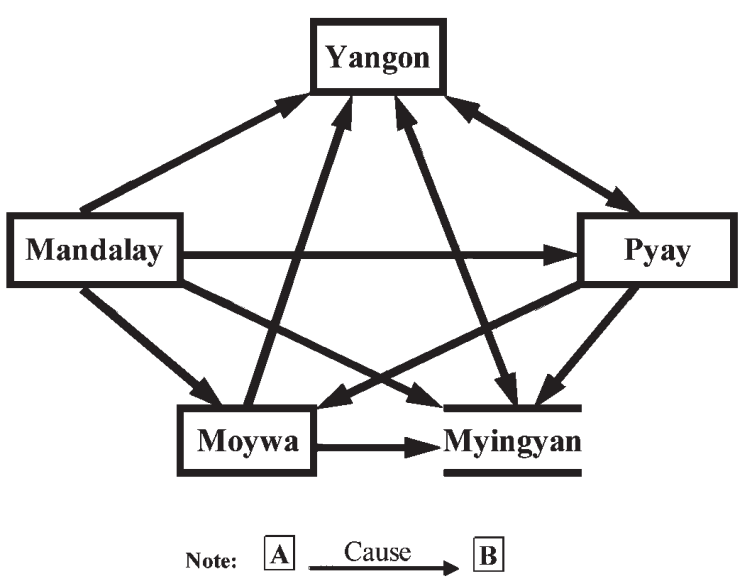

Fig. 4b. The direction of Causality of Green Gram Price.

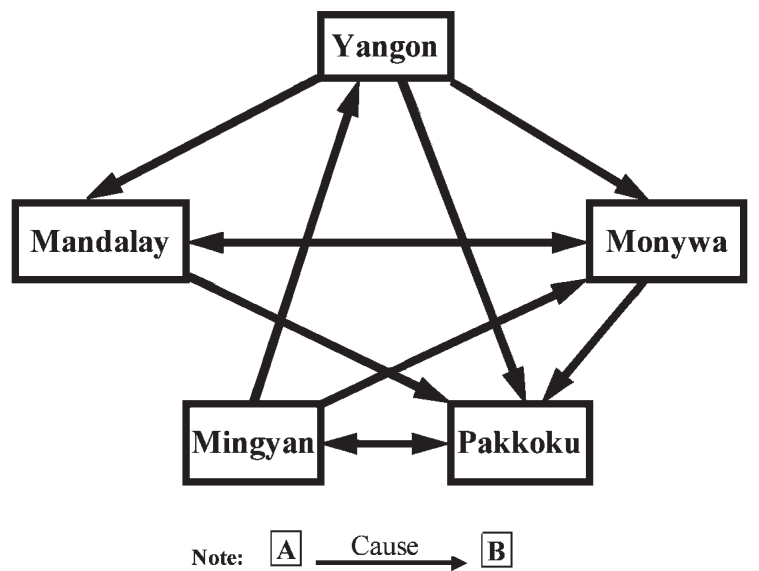

Fig. 4c. The direction of Causality of Pigeon pea Price.

pairs of feedback movement: Mandalay and Moywa, and Myingyan and Pakkoku.

Among pulses markets, Yangon and Mandalay markets are the leading markets for price formation. Moreover, it can be said that there are monopolistic behaviors and asymmetry transmission of price information because the unidirectional movements of prices in markets are found in Granger causality test results.

\section{CONCLUSIONS}

Although agricultural market reform with domestic and export liberalization encourages the degree of market integration, there is a weak market integration and asymmetry transmission of price information among markets. Long-run market performance is good for all markets, but there is disequilibrium condition in short run market integration. The major impediments of market integration are inefficient market institutions, poor market infrastructure, and inadequate market information systems.

The transmission of price formation is informal and individual within wholesalers and their clients in all markets. Although market information service administered by department of agricultural planning, collects price information and disseminates price information with MIS bulletin and the Agri-business news to the farmers and marketing participants, the price information cannot be effectively used by farmers and marketing participants because they do not have enough knowledge for understanding price information, and the distribution and number of copies are limited.

There is no department or division with a title of agricultural marketing in any of ministries, and it is unclear which ministry is in charge of the adjustment of demand and supply of agricultural products, report of balance sheet and price stabilization. At present, most markets of agricultural products are managed and administered by Yangon City Development Council for taxing the markets and renting the buildings. This council just manages the market infrastructure and does not have any responsibility for market improvement although council gets many revenues by taxing.

To achieve the efficient marketing system, market information service should be strengthened by increasing the efficient distribution of the MIS price bulletin and agri-business news. And also, investment in marketing facilities in both rural and urban areas should be increased for modernization of agricultural marketing systems. It can be concluded that agricultural market reform with domestic and export liberalization is necessary condition for efficient marketing system, but is not a sufficient condition for this system, and efficient marketing system should be improved with agricultural market reform meanwhile strengthening market information system, market facilities and institutions.

\section{REFERENCES}

Dickey, D. A., and W. A. Fuller 1979 Distribution of the Estimators for Autoregressive Time Series with a Unit Root. Journal of the American Statistical Association, 79: 427431

Dickey, D. A., and W. A. Fuller 1981 Likelihood Ratio Statistics for Autoregressive Time Series in a Unit Root. Econometica, 49: 1057-1072

Engle, R. F. and Granger, C. W. J. 1987 Cointegration and error correction: representation, estimation and testing. Econometrica, 55: 251-276

Food and Agricultural Organization (FAO) 2000 Agricultural Marketing in Myanmar. Ministry of Agriculture and 
Irrigation, Yangon

Granger, C. W. J. 1969 Investigating Causal Relationships by Econometric Models and Cross Spectral Methods. Econometrica, 37: 424-438

Johansen, S. 1991 Estimation and Hypothesis Testing of Cointegration Vectors in Gaussian Vector Autoregressive Models. Econometrica, 56(6): 1551-1580

Johansen, S. and Juselius, K. 1990 Maximum Likelihood Estimation and Inference on Cointegration. Oxford Bulletin of Economics and Statistics, 52(2): 169-210

Luu Thanh Duc Hai 2003 Rice Markets in the Mekong River
Delta, Vietnam: A market integration analysis. CAS Discussion Paper, 40, Center for ASEAN Studies. Catho University, Catho, Vietnam

Ravillion, M. 1986 Testing Marketing Integration. American Journal of Agricultural Economics, 68(2): 292-307

Walter Enders 1995 Applied Econometric Time Series. John Wiley \& Sons, Inc., U.S.A

Yoon Hoseop and Huh Gilhaeng 2003 Policy Directions of Agricultural Marketing in the Union of Myanmar. Journal of Rural Development, 26: 67-97 